Rev. Biol. Trop. 46(4): 1173-1183, 1998

www.ucr.ac.cr www.ots.ac.cr www.ots.duke.edu

\title{
Comparisons between nine-banded armadillo (Dasypus novemcinctus) populations in Brazil and the United States
}

\author{
W. J. Loughry and Colleen M. McDonough
}

Department of Biology, Valdosta State University, Valdosta, GA 31698-0015, U.S.A. Fax: 912-333-7389; email: jloughry@valdosta.edu

Received 21-IV-1998. Corrected 10-VIII-1998. Aceptado 20-VIII-1998.

\begin{abstract}
We compared characteristics of a population of nine-banded armadillos (Dasypus novemcinctus) studied in the southern United States with a population found in the Atlantic coastal rainforest of Brazil. Adult armadillos in Brazil weighed less than those in the U.S., but when weight was accounted for, did not differ in other measures of body size. However, juveniles in the U.S. were proportionately bigger than those in Brazil. Armadillos in Brazil were less abundant (numbers sighted per $\mathrm{h}$ of observation) and were active later at night than those in the U.S. Adult sex-ratios were male-biased in both populations: Finally, there was no significant difference in the incidence of littermate associations observed in the two populations, but groups of juveniles (which included non-littermates) were observed more frequently in the U.S. Many of these differences may be due to the fact that armadillos are hunted extensively in Brazil but not in the United States.
\end{abstract}

Key words: Dasypus novemcinctus, armadillos, Brazil, United States, population differences.

Many charactersitics of animal populations vary intraspecifically, presumably as the result of adaptation to conditions that vary geographically (Lott 1991, Foster and Endler in press). Comparisons of populations inhabiting different areas can yield insights into the evolutionary forces generating differences between populations. In addition, the extent of intraspecific variation provides information on how generalizable data from one population are to populations in other parts of a species' range.

Nine-banded armadillos (Dasypus novemcinctus) are found from northern Argentina to the southern United States (Humphrey 1974, Wetzel 1982, 1985, Taulman and Robbins 1996). They are relatively asocial, burrowing mammals (Newman 1913, Galbreath 1982, McBee and Baker 1982), that are mostly active at night (McDonough and Loughry 1997a), and feed primarily on insects (Kalmbach 1943, Clark 1951, Fitch et al. 1952,
Breece and Dusi 1985, Redford 1985, Sikes et al. 1990, Lippert 1994). Females give birth to litters of genetically-identical quadruplets in the spring (Newman and Patterson 1910, Patterson 1913, Storrs and Williams 1968, Prodöhl et al. 1996), with litters first emerging from their natal burrows from late spring through the summer (Loughry and McDonough 1994). Juveniles (young of the year) remain in close proximity, foraging together and sharing the same burrows through some of their first summer (Taber 1945, Galbreath 1982, McDonough and Loughry 1995, Prodöhl et al. 1996), but litters appear to break up (due to dispersal or mortality) by the fall (McDonough and Loughry unpublished data).

The above account is potentially problematic because almost all of this information is derived from studies performed in the northern-most part of the species' range (i.e., in the United States; reviews in Kalmbach 1943, Taber 1945, Talmage and Buchanan 
1954, Galbreath 1982, McBee and Baker 1982). Nine-banded armadillos have only recently colonized the U.S. (Humphrey 1974, Taulman and Robbins 1996), so data from these studies may not be representative of populations in more ancient parts of the species' range, living in the kinds of conditions under which the species presumably evolved. Comparisons with nonNorth American populations of $D$. novemcinctus are required to determine if this is a legitimate concern. In this study, we addressed this issue by collecting data on a population of nine-banded armadillos located in northern Florida (Loughry and McDonough 1996, McDonough and Loughry 1997a) and, using the same methods, a population located in the Atlantic coastal rainforest of Brazil. These two data sets provide an opportunity to examine the question of how similar armadillos are in these two widely separated locales. While our data are not an exhaustive account of the population attributes of armadillos in either location, they allow at least a preliminary assessment of the extent of intraspecific variation that can occur in $D$. novemcinctus.

\section{MATERIALS AND METHODS}

Data on Brazilian armadillos were collected from 20 January-1 June, 1996, at the Poço das Antas Biological Reserve (5500 ha), lecated approximately $70 \mathrm{~km}$ north of Rio de Janiero. The reserve contains one of the largest remaining fragments of Atlantic coastal rainforest and is the site of conservation efforts to preserve the golden-lion tamarin (Leontopithecus rosalia, Kleiman et al. 1986, Dietz et al. 1997). Data for the U.S. come from a four year (1992-1995) study of armadillos located on the Tall Timbers Research Station (1600 ha), near Tallahassee, Florida (see Loughry and McDonough 1996, McDonough and Loughry 1997a). There was some year-toyear variation in the characteristics of the Florida population (Loughry and McDonough 1996, McDonough and Loughry 1997a), but in the analyses reported here we pooled data over the entire four year period for comparison with those collected in Brazil. While this makes the U.S. data set large in comparison with that from Brazil, it seems appropriate because we are interested in average differences between the two populations, rather than transient differences due to yearly variation. However, to insure that pooling was appropriate, we performed separate comparisons of each year's data from Tall Timbers with the Brazilian data and obtained exactly the same pattern of results.

Data collection followed procedures developed during the Florida study (McDonough and Loughry 1997a, Loughry and McDonough 1998). In both populations, we censused the property during both daylight and evening hours (200 days for a total of 2273 person-hours of field time in the U.S., in Brazil, 108 days and 958 person-hours). A daily census typically lasted $4-6 \mathrm{~h}$ and was conducted by walking or driving along trails or roads on each property. Spotlights and miner's lamps were used to observe animals after dark. The total linear distance censused was approximately $25 \mathrm{~km}$ at each site. A rotating schedule of observations was used, such that a portion of the entire sampling area was censused each night, followed by another portion the next night, and so on until the entire area had been sampled. This schedule was then repeated for the duration of the field season. Both sites were comprised of a variety of habitat types (in Brazil: rainforest, swamp, grassland and disturbed habitats, see Dietz et al. 1997, Loughry and McDonough 1997, in the U. S.: hardwood hammocks, wetlands, fields and upland pine areas, Brennan et al. 1998). Visibility to the sides of roads and trails varied considerably depending on habitat type. While we did not attempt to measure visibilities systematically in the two locales, it was our impression that they were relatively similar overall. Thus, the total area sampled at each site was roughly the same.

We attempted to capture armadillos observed during censuses with large dip nets attached to a $1.5 \mathrm{~m}$ pole. In Brazil, we also 
used live-traps placed in the mouths of active burrows. Once caught, animals were sexed, weighed, and marked for long-range identification by gluing unique colors and shapes of reflective tape on various parts of the carapace. A small tissue sample for genetic studies was taken from one or both ears using an ear-notcher. These notches were taken from different locations on the ears of different individuals, further contributing to identification of particular animals. Animals were marked for permanent identification using ear tags and, in the U.S., with passive transponder (PIT) tags. Five body size measurements (all in $\mathrm{cm}$ ) were obtained from all captured animals: (1) tail base $=$ the circumference of the tail at its juncture with the body near the pelvic shield of the dorsal carapace; (2) tail length = the length of the tail from the base to the tip (animals who were missing a portion of the tail were not measured); (3) front carapace = the length of the anterior edge of the scapular shield of the carapace (i.e., at the juncture with the head); (4) front band $=$ the length of the posterior edge of the scapular shield; and (5) back band = the length of the most posterior movable band. Animals were assigned to age categories based on weight (McDonough 1992, 1994, Loughry and McDonough 1996) as juveniles (young of the year, $<2.5 \mathrm{~kg})$, yearlings $(2.5-3.5 \mathrm{~kg})$, or adults $(>3.5 \mathrm{~kg}$ ). Because of the smaller size of Brazilian armadillos (see below), individuals there were only classified as adults $(\geq 2.5 \mathrm{~kg}$ ) or juveniles $(<2.5 \mathrm{~kg})$. Consequently, we omitted the yearling age class of U.S. animals from all of the analyses reported here. Finally, the time of day (in local DST) at which the animal was first seen was recorded.

During our censuses we observed more armadillos than we were able to catch. For these individuals we noted the time at which the animal was sighted and its age (as either juvenile or adult on the basis of body size). If the genitalia were visible we were able to classify the individual by sex as well. The seven-banded armadillo, D. septemcinctus, also occurs at Poço das Antas (Loughry and McDonough 1997) and juvenile $D$. novemcinctus appear very similar to adult $D$. septemcinctus. Thus, our data on juvenile abundances and the timing of activity may be slightly biased by the inclusion of some data from $D$. septemcinctus. This is unlikely to be a large problem because $D$. septemcinctus was relatively rare on the reserve and typically found in different habitats from $D$. novemcinctus (Loughry and McDonough 1997). In addition, most observations of juvenile $D$. novemcinctus were from animals that had been captured, marked and subsequently resighted.

Using the data collected by these methods, we compared five characteristics of our two populations. (1) We compared morphology by analyzing differences in body weight and body size measurements with t-tests. Body size measurements are correlated with body weight (Loughry and McDonough 1996), so we performed a second analysis of body size differences using an ANCOVA in which body weight was the covariate. For both sets of analyses, we averaged data for individuals with multiple measurements (except where the animal changed age groups, e.g., data for an individual first caught as a juvenile then subsequently as an adult were not averaged but treated as independent points). Although armadillos may exhibit some sexual dimorphism (McDonough 1992), we pooled data for males and females in these analyses because we found little evidence of sexual dimorphism in our populations and because the small number of females caught in Brazil (see below) did not permit statistical examination of body size for each sex separately. (2) We compared abundances by calculating the number of individuals (adults, juveniles, and total animals) observed per $\mathrm{h}$ of observation in each locale. These data were further subdivided into the number of animals observed during daylight hours (8:00-16:00 local DST) and at night (16:00-24:00 local DST; cf. McDonough and Loughry 1997a). Comparisons between the two populations were made using t-tests. (3) We further examined activity by using t-tests to compare the times of day when individuals were first 
sighted in the two populations (cf. McDonough and Loughry 1997a). These data included sightings of animals that were subsequently captured as well as animals that were seen but not caught. All times were in local DST. There is a potential problem with this analysis in that we observed armadillos in Brazil during the austral summer and on through the fall, when hours of daylight were diminishing (all data for the U.S. come from June-August). Thus, it is possible we might find no difference between U.S. and Brazilian armadillos in the time of day at which they were observed, but Brazilian armadillos would have been active after dark whereas U.S. animals would have been active during daylight. In an attempt to eliminate this problem, we performed a second analysis in which we subtracted the time of sunset from the time at which an animal was observed. Thus, animals with positive values were observed after sunset and those with negative values before sunset. Data on the timing of sunset at each site were obtained from the Astronomical Almanac (U.S. Naval Observatory 1995). (4) Sex-ratios of adults, juveniles and the entire population were compared between the two sites using data from captured animals. Because litters consist of identical quadruplets (Newman and Patterson 1910, Newman 1913, Storrs and Williams 1968, Prodöhl et al. 1996), it may be more appropriate to examine sexratios of litters rather than of individual juveniles. In our analyses we compared juvenile sex-ratios using both numbers of male and female litters and numbers of male and female individuals. Littermates were identified using microsatellite DNA markers (Prodöhl et al. 1996). Sex-ratios within populations were compared using Chi-square tests and between populations with Fisher's exact tests.

Juvenile armadillos tend to associate (e.g., forage together) with their littermates for some time after they first emerge from their natal burrows (Loughry and McDonough 1994, McDonough and Loughry 1995, Prodöhl et al. 1996, Loughry and McDonough 1998). Although we caught a number of juveniles in Brazil (see below), we rarely observed littermate associations. In contrast, we often observed such groups in the U.S. To evaluate this difference we determined, for each population, the number of litters in which a juvenile was observed with at least one other littermate. Multiple observations of the same litter were ignored so that if a litter was observed as an association at least once, it was classified as exhibiting association. Only litters in which a juvenile was never observed with a sibling were classified as singletons. We then compared the proportion of singletons between the two populations using Fisher's exact test. This analysis used data from litters identified with microsatellite DNA markers (Prodöhl et al. 1996). We also performed a second analysis in which we examined the number of times juveniles in each population were observed alone versus in proximity to another juvenile (regardless of whether this other juvenile was a littermate or not). Again, we pooled data from the same individuals so that if a juvenile was observed associating with another juvenile at least once, it was classified as exhibiting association. The incidence of singletons observed in each population was then compared with Fisher's exact test.

A final note concerns comparisons between juveniles at the two sites. Such comparisons are potentially problematic if juveniles are not of similar age. For example, larger body size or the absence of littermate associations could be due to juveniles at one site being older than juveniles at the other site. There are several lines of evidence that suggest this was not the case. First, field assistants involved in the golden-lion tamarin project at Poço das Antas reported first observing juvenile armadillos at the beginning of the austral summer (late November to early December), which is similar to the timing of emergence from natal burrows at Tall Timbers (i.e., at the beginning of summer in May or early June; Loughry and McDonough 1994). These assistants are in the reserve from dawn to dusk six days a week each week of the year. As such, they are the individuals most likely to encounter juvenile armadillos and thus, their 
observations can be considered reliable. In addition, the timing of juvenile emergence at Poço das Antas is consistent with data documenting the timing of births for a population in Paraguay. In Paraguay, most births occurred in September or early October (K. Hill pers. comm.), which would lead to juvenile emergence in November or December. Thus, we conclude that the majority of juveniles in our two populations were of similar age.

\section{RESULTS}

Body size: Both adult and juvenile ninebanded armadillos in the U.S. were significantly covariance with body weight as the covariate showed that, for a given body weight, adult armadillos in the U.S. and Brazil did not differ in any body size measurement (all $\mathrm{p}>0.05$ ). However, juveniles in the U.S. had proportionately larger front band $(p=0.02)$ and front carapace lengths $(p=0.045)$ than did Brazilian juveniles, even when variation in body weight was accounted for.

Abundance: The total number of armadillos observed per $\mathrm{h}$ of observation was significantly greater in the U.S. than in Brazil whether one compared the number of animals sighted over the entire daily sampling period,

TABLE 1

Mean ( \pm SE) body size measurements of nine-banded armadillos in Brazil and the United States

Poço das Antas

Measure
Weight $(\mathrm{kg})$
Front carapace $(\mathrm{cm})$
Front band $(\mathrm{cm})$
Back band $(\mathrm{cm})$
Tail base $(\mathrm{cm})$
Tail length $(\mathrm{cm})$
$\mathrm{n}$

Juveniles

$1.16(0.14)$

$14.26(0.58)$

$21.31(1.02)$

$21.85(1.16)$

$9.39(0.50)$

$23.18(1.10)$

larger than their Brazilian counterparts (Table 1). Adults were significantly different in every measurement (ANCVA, all $\mathrm{p} \leq 0.0001$ ), while juveniles differed in front carapace length $(\mathrm{p}=$ $0.04)$ and tail length $(p=0.0012)$. Analysis of

Adults
$3.13(0.08)$
$19.97(0.22)$
$31.00(0.35)$
$33.02(0.30)$
$13.66(0.16)$
$27.96(0.59)$

only during the daytime, or only at night (Table 2). This same pattern was found when data for adults were analyzed separately (Table 2). Juveniles were also more abundant in the U.S. than in Brazil when the data included the

TABLE 2

Average number of armadillos observed per $h$ of observation $( \pm S E)$ in Brazil and the United States. Sample sizes are the number of days of observation. Statistical comparisons are within each row with $* p<0.05, * * p<0.01, * * * p<0.001$

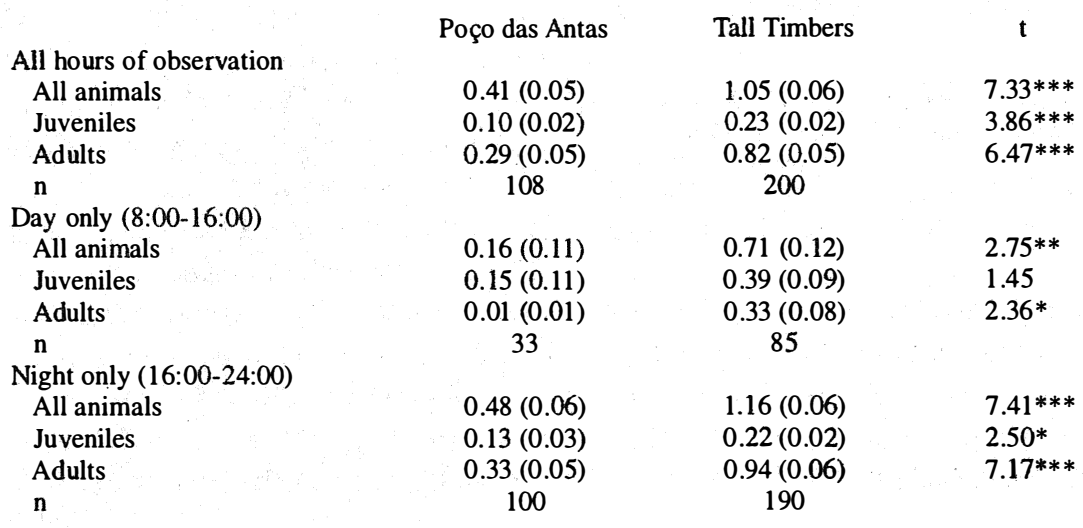


entire day or nighttime only (Table 2). However, juvenile abundances did not differ during daytime (Table 2).

Activity: The time of day when armadillos were first observed was significantly later in Brazil than in the U.S. in not be determined, they are excluded from Table 4). In the U.S., the overall sex-ratio was not significantly biased (Chi-square $=0.46, \mathrm{p}>$ 0.25 ), but was male-biased for adults (Chisquare $=5.21, \mathrm{p}<0.025)$ and female-biased for juveniles (Chi-square $=4.20, \mathrm{p}<0.05$;

TABLE 3

Average time of first sighting ( $\pm S E$ ) for nine-banded armadillos in Brazil and the United States. Sample sizes for adults and juveniles in each population do not add up to the sample size for all animals because in some cases we observed individuals briefly and could not reliably age them. These animals are included in the all animals category, but excluded from the age group data. Statistical comparisons are within each row with $* p<0.05, * * p<0.01, * * * p<0.001$

All animals
Time of day
Hours from sunset
$\mathbf{n}$
Juveniles only
Time of day
Hours from sunset
$\mathbf{n}$
Adults only
Time of day
Hours from sunset
$\mathbf{n}$

Poço das Antas

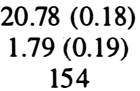

$19.23(0.39)$

$-0.22(0.45)$

35

$20.99(0.16)$

$2.21(0.17)$

101

$\begin{array}{cc}\text { Tall Timbers } & \mathrm{t} \\ 19.31(0.07) & 6.99 * * * \\ -0.71(0.07) & 11.73 * * * \\ 1155 & \\ & \\ 17.61(0.19) & 3.04 * * \\ -2.40(0.19) & 3.99 * * * \\ 265 & \\ & \\ 19.82(0.07) & 5.60 * * * \\ -0.21(0.07) & 11.46 * * * \\ 883 & \end{array}$

comparisons using data from all animals, and when adults and juveniles were analyzed separately (Table 3 ). Analyzing the timing of activity relative to sunset showed again that, in all cases, Brazilian armadillos were active later than those in the U.S. (Table 3).

Sex-ratios: There was evidence of sexratio biases within each population (Table 4). In Brazil, the overall population sex-ratio was

\section{TABLE 4}

Sex-ratios of adult and juvenile armadillos in Brazil and the United States. For juveniles, the number of litters are indicated parenthetically

\begin{tabular}{lcccc} 
& \multicolumn{2}{c}{ Poço das Antas } & \multicolumn{2}{c}{ Tall Timbers } \\
Group & Males & Females & Males & Females \\
All animals & 25 & 10 & 163 & 151 \\
Adults only & 16 & 6 & 121 & 88 \\
Juveniles only & $9(9)$ & $4(4)$ & $42(31)$ & $63(38)$
\end{tabular}

significantly male-biased (Chi-square $=6.43, \mathrm{p}$ $<0.025$ ) as was the sex-ratio for adults (Chisquare $=4.55, \mathrm{p}<0.05$; Table 4$)$, but not for juveniles (Chi-square $=1.92, \mathrm{p}>0.10$; two juveniles were found dead and their sex could

Table 4). The sex-ratio bias for juveniles in the U.S. disappeared when the number of male and female litters were compared rather than the number of individuals (Chi-square $=0.71$, $\mathrm{p}>0.25)$. The overall sex-ratio differed between the two populations (Fisher's test, $\mathrm{p}=$ 0.03 ), but not when adults and juveniles were examined separately (for juveniles this included comparisons of numbers of male and female litters as well as numbers of individuals, all $\mathrm{p}>0.07$ ).

Associations among juveniles: In Brazil we observed a littermate association in only one of 15 litters $(6.7 \%)$. Littermate associations occurred in 18 of 69 litters (26.1\%) in the U.S., but the difference in the proportion of litters observed as singletons in the two populations was not significant (Fisher's test, $\mathrm{p}=0.17$ ). However, juveniles did associate with one another more frequently in the U.S. when associations with nonlittermates were included. Groups of juveniles were observed in 27 of 56 cases (48\%) in the U.S., but just once in 15 instances in Brazil. This difference in the proportion of juveniles 
observed as singletons was significant between the two populations (Fisher's test, $\mathrm{p}=0.003$ ).

\section{DISCUSSION}

Our results demonstrate that substantial differences do exist between at least one population of $D$. novemcinctus in Brazil and one in the United States. Armadillos at Poço das Antas were less abundant, smaller, and active later at night than armadillos at Tall Timbers. In addition, the Brazilian population exhibited a strongly male-biased sex-ratio and a lack of association among juveniles. Two valid criticisms of this study concern the relatively small sample size from Brazil, particularly for comparisons of body sizes and sex-ratios, and the fact that all the Brazilian data were derived from a single field season. With regard to sample size, we would point out that our data represent the largest reported sample from a Brazilian population of $D$. novemcinctus (cf. Wetzel and Mondolfi 1979, Wetzel 1982, Carter and Encarnação 1983, Schaller 1983, Carter 1985, Redford 1994). In addition, although our Brazilian data come from a single field season, this field season lasted twice as long as one of our field seasons in the U. S. (> 100 days versus ca. 50 days), so our sampling effort in Brazil represents the equivalent of over 2 years of data collection in the U. S. Finally, as mentioned earlier, when we compared our Brazilian data separately with each year of data from Tall Timbers, the same pattern of differences emerged (note that these analyses reversed the problem such that the Brazilian data set was now twice as large as that from the U.S.). Thus, we believe our data provide an adequate basis for evaluating potential variation between the two populations.

Another important issue concerns how representative these two populations are of North and South American populations in general. North American populations of $D$. novemcinctus can vary dramatically, e.g., in sizes of home ranges and in the incidence of aggression (review in McDonough 1992). Thus, the differences we report between Brazil and the U. S. may be no more extensive than the differences between various $U$. S. populations. At present, we cannot completely address this issue because, with the exception of body size, there are no published data on the variables we measured for any other $D$. novemcinctus population. Adult body weights of $D$. novemcinctus range from $3-7 \mathrm{~kg}$ (McBee and Baker 1982). However, consistent with the findings of the present study, populations found north of the Amazon appear to weigh more than those found south (Wetzel and Mondolfi 1979, Wetzel 1982, Schaller 1983, Redford 1994, but see Hill et al. 1997). Such differences occur in other aspects of morphology as well. For example, South American populations of $D$. novemcinctus often have only eight movable bands whereas populations in the U.S. normally have nine or more (Wetzel and Mondolfi 1979, Wetzel 1982, 1985).

Setting aside the issue of how representative our two populations are of North and South American populations in general, it still remains to explain why our two populations were so different from one another. One possible explanation concerns the fact that humans hunt armadillos extensively (albeit, illegally) at Poço das Antas (C. Ruiz-Miranda pers. comm.) but not at Tall Timbers. Although we had no problems in detecting armadillos at a distance in Brazil, it was much more difficult to approach active animals in order to catch them. Almost invariably, our approach was detected before we were close enough to use our nets and, upon detection, the animals immediately ran into the forest. At Tall Timbers, mortality from human hunters is almost non-existent (pers. observ.) and we rarely have problems with animals fleeing from us before we can attempt to capture them. While we did not attempt to do so, it would be interesting to compare levels of vigilance in the two populations (e.g., McDonough and Loughry 1995). We predict that Brazilian armadillos will be more vigilant than those in the U.S., thus enabling them to detect potential predators sooner. The influence of human hunting could account for 
many of the differences between the two populations. For example, hunting could generate the lower abundances (see also Hill et al. 1997) and later timing of activity exhibited by Brazilian armadillos, and might contribute to the lack of associations among juveniles observed in Brazil either directly by removing young or indirectly by promoting the break-up of litters to avoid detection by human "predators". However, the impact of hunting on Brazilian armadillo populations will be difficult to evaluate because, as hunting is illegal, hunters are unwilling to supply data on hunting success or the demography of killed individuals.

Hunting by humans is the most conspicuous difference in sources of mortality between our two populations, but it is possible that differences in the types of non-human predators present at each site also contribute to the population differences we report. However, this seems unlikely to be a major influence. There are few large predators present at either site capable of killing an adult armadillo (pers. observ.). Juvenile mortality due to predation can be quite high in the U. S. (McDonough and Loughry 1997b) and we have no evidence to suggest that it is significantly higher in Brazil. Nonetheless, additional data will be required to determine the potential importance of nonhuman predators in generating the differences between our two populations.

One alternative to hunting as an explanation for the differences between Brazilian and U.S. armadillos is that, in the U.S., D. novemcinctus is the only xenarthran present, whereas in Brazil there are more species of armadillos (Cabassous unicinctus and Dasypus septemcinctus; Euphractus sexcinctus used to occur but may now be locally extinct; Loughry and McDonough 1997) as well as the southern collared anteater (Tamandua tetradactylus; Loughry and McDonough 1997). Thus, competitive interactions with other xenarthra in Brazil might lead to lower abundances as well as alterations in the timing of activity so as to avoid overlap with these other species. This explanation seems unlikely for several reasons.
All other xenarthra at Poço das Antas were rare (Loughry and McDonough 1997), so it seems improbable that competition among these species is severe. D. novemcinctus is among the largest of the armadillos present (Loughry and McDonough 1997) and thus it seems likely that the other species would show more negative effects of competition with ninebanded armadillos than vice-versa. Data on habitat preferences suggest that each species utilizes different parts of the reserve, minimizing opportunities for competitive interactions (Loughry and McDonough 1997), and $D$. novemcinctus occupies what are presumably the most favorable sites (i.e., in primary forest, near the rich feeding grounds of the swamps; Loughry and McDonough 1997), so they would seem least likely to be impacted by the presence of other xenarthra.

Extensive hunting of armadillos in Brazil may explain some of the observed differences between U.S. and Brazil populations, but it seems unlikely to explain differences in body size and sex-ratio biases. Hunting could explain body size differences if hunters preferentially took only large animals (but see Abrams and Rowe 1996), but it appears that most hunting involves setting traps in burrows or across heavily used trails (C. Ruiz-Miranda pers. comm.), so large individuals would be unlikely to be selectively taken. Bergmann's rule (e.g., James 1970) is also an unlikely explanation. Tall Timbers is further north of the equator (latitude $=30^{\circ} 40^{\prime}$ ) than Poço das Antas is south (latittude $=22^{\circ} 31^{\prime}$ ) so a latitudinal gradient in body size might seem plausible. However, Wetzel and Mondolfi (1979) report data from $D$. novemcinctus populations in Venezuela which are as large as the animals in Florida. Results of analysis of covariance showed that U.S. juveniles were proportionately bigger than their Brazilian counterparts when variation in body weight was accounted for, suggesting that larger adult size is accomplished by increased growth as juveniles. Whether this represents a genetic change in developmental growth patterns or merely a response to increased resource availability is unknown. 
Sex-ratios of adults in both Brazil and the U.S. were male-biased. The skew found in Brazil could be due to small sample size, but the fact that the same pattern was found in the U.S. suggests that this could be an intrinisic feature of nine-banded armadillo populations. However, other U.S. populations do not show such a bias, nor was one detected at Tall Timbers during the first three years (19921994) of our study (Loughry and McDonough 1996). Assuming the bias we have detected is real, it is unclear why it exists. In the U.S., juvenile males are actually less abundant than juvenile females (though not in terms of the numbers of litters produced, see Table 4). This suggests that there may be either increased mortality or a higher probability of dispersal out of the population for females as they get older. Alternatively, adult females might be less active or less detectable than are adult males, but we know of no data to support such a hypothesis. Juvenile mortality can be high (McDonough and Loughry 1997b), but we currently do not have data on sex differences in mortality. Recruitment into our Florida population is low for both sexes (Loughry and McDonough 1996, 1998), but there is some evidence that females may be less likely to remain in their natal population than males (Loughry and McDonough 1998). However, any explanations of sex-ratio biases will probably require additional data to confirm that such a bias is real.

Most earlier studies of $D$. novemcinctus have been performed in the U.S., with populations that have presumably been established for at most 100 to 200 years (Humphrey 1974, McBee and Baker 1982, Montgomery 1985, Wetzel 1985, Taulman and Robbins 1996). We have shown here that at least one U.S. population differs substantially from a population located in a more historically ancient part of the species' range (i.e., Brazil). Thus, the question arises of how representative data on U.S. populations are for the species as a whole. At present we cannot answer this question. The extensive hunting of armadillos that occurs at our Brazilian study site confounds any comparisons based on other differences. An appropriate comparison would require a non-hunted South American population. Such a population may be difficult to find as armadillos are apparently a favored food item in many countries (Eisenberg 1989, Emmons 1990, Redford and Eisenberg 1992, Taulman and Robbins 1996, Hill et al. 1997). Nonetheless, our data do suggest caution in making generalizations about nine-banded armadillos based on data from just the United States, and point out the need for more data on more populations of $D$. novemcinctus in other parts of the species' range.

\section{ACKNOWLEDGMENTS}

We are extremely grateful to C. RuizMiranda of the Smithsonian Institution (National Zoo) for encouraging us to pursue study of Brazilian armadillos. Our Brazilian work would not have been possible without the exceptional armadillo-catching abilities of $\mathbf{M}$. Coelho, to whom we are deeply indebted. Work in Brazil was supported by an Organization of American States Fellowship (to W. J. L.), a Valdosta State University faculty research award (to C. M. M.), the Smithsonian Institution, TransBrasil, and the Associação Mico-Leão-Dourado (AMLD). Thanks also to the director of AMLD, D. Rambaldi, and the director of Poço das Antas, D. Pessamílio, for facilitating our research. In the U.S., we are grateful to T. Engstrom and L. Brennan of Tall Timbers Research Station for their continued support of our research. Our armadillo studies in the U.S. have been funded by the American Philosophical Society and Valdosta State University faculty research awards to W. J. L., and by Sigma Xi, the Theodore Roosevelt Memorial Fund, and Valdosta State University faculty research awards to C. M. M.

\section{REFERENCES}

Abrams, P. A. \& L. Rowe. 1996. The effects of predation on the age and size of maturity of prey. Evolution 50: $1052-1061$. 
Breece, G. A. \& J. L. Dusi. 1985. Food habits and home ranges of the common long-nosed armadillo Dasypus novemcinctus in Alabama, p. 419-427. In G. G. Montgomery (ed.). The evolution and ecology of armadillos, sloths, and vermilinguas. Smithsonian Instit., Washington, D.C. 451 p.

Brennan, L. A., R. T. Engstrom, S. M. Hermann, S. T. Lindeman, W. K. Moser, K. McGorty, J. Noble \& W. E. Palmer. 1998. A five-year land management plan for Tall Timbers Research Station property: 1998-2002. Tall Timbers Research Station, Tallahassee. $106 \mathrm{p}$.

Carter, T. S. 1985. Armadillos of Brazil. Nat. Geog. Res. Rep. 20: 101-107.

Carter, T. S. \& C. Encarnação. 1983. Characteristics and use of burrows by four species of armadillos in Brazil. J. Mammal. 64: 103-108.

Clark, W. K. 1951. Ecological life history of the armadillo in the eastern Edwards Plateau region. Amer. Midl. Nat. 46: 337-358.

Dietz, J. M., C. A. Peres \& L. Pinder. 1997. Foraging ecology and use of space in wild golden lion tamarins (Leontopithecus rosalia). Amer. J. Primat. 41: 289-305.

Eisenberg, J. F. 1989. Mammals of the neotropics. Vol. 1. The northern tropics. Univ. Chicago, Chicago. $449 \mathrm{p}$.

Emmons, L. H. 1990. Neotropical rainforest mammals: a field guide. Univ. Chicago, Chicago. 281 p.

Fitch, H. S., P. Goodrum \& C. Newman. 1952. The armadillo in the southeastern U. S. J. Mammal. 33: 21-37.

Foster, S. A. \& J. A. Endler. (eds.). in press. Geographic variation in behavior: perspectives on evolutionary mechanisms. Oxford Univ., Oxford.

Galbreath, G. J. 1982. Armadillo, p. 71-79. In J. A. Chapman \& G. A. Feldhamer (eds.). Wild mammals of North America. Johns Hopkins Univ., Baltimore. $1147 \mathrm{p}$.

Hill, K., J. Padwe, C. Bejyvagi, A. Bep rangi, F. Jakugi, R. Tykuarangi \& T. Tykuarangi. 1997. Monitoring hunting impact on large vertebrates in the Mbaracayu reserve, Paraguay, using native research assistants. Cons. Biol. 11: 1339-1353.

Humphrey, S. R. 1974. Zoogeography of the nine-banded armadillo in the United States. Bioscience 24: 457462 .
James, F. C. 1970. Geographic size variation in birds and its relationship to climate. Ecology 51: 365-390.

Kalmbach, E. R. 1943. The armadillo: its relation to agriculture and game. Texas Game, Fish and Oyster Commission, Austin. $61 \mathrm{p}$.

Kleiman, D. G., B. B. Beck, J. M. Dietz, L. A. Dietz, J. D. Ballou \& A. F. Coimbra-Filho. 1986. Conservation program for the golden lion tamarin: captive research and management, ecological studies, education strategies and reintroduction, p. 959-979. In K. Benirschke (ed.). Primates: the road to self-sustaining populations. Springer-Verlag, New York. 1044 p.

Lippert, K. J. 1994. Food habits, distribution and impact of the nine-banded armadillo in Missouri. M.S. thesis, Southwest Missouri State University, Springfield. $88 \mathrm{p}$

Lott, D. F. 1991. Intraspecific variation in the social systems of wild vertebrates. Cambridge Univ., Cambridge. $238 \mathrm{p}$.

Loughry, W. J. \& C. M. McDonough. 1994. Scent discrimination by infant nine-banded armadillos. J. Mammal. 75: 1033-1039.

Loughry, W. J. \& C. M. McDonough. 1996. Are road-kills valid indicators of arrnadillo population structure? Amer. Midl. Nat. 135: 53-59.

Loughry, W. J. \& C. M. McDonough. 1997. Survey of the Xenarthrans at Poço das Antas Biological Reserve. Edentata 3: 5-7.

Loughry, W. J. \& C. M. McDonough. 1998. Spatial patterns in a population of nine-banded armadillos (Dasypus novemcinctus). Amer. Midl. Nat. 140: 161-169.

McBee, K. \& R. J. Baker. 1982. Dasypus novemcinctus. Mammal. Spec. 162: 1-9.

McDonough, C. M. 1992. The behavior and ecology of nine-banded armadillos (Dasypus novemcinctus) in south Texas. Ph. D. Thesis, University of California, Davis. $101 \mathrm{p}$.

McDonough, C. M. 1994. Determinants of aggression in nine-banded armadillos. J. Mammal. 75: 189-198.

McDonough, C. M. \& W. J. Loughry. 1995. Influences on vigilance in nine-banded armadillos. Ethology 100: 50-60

McDonough, C. M. \& W. J. Loughry. 1997a. Influences on activity pattems in a population of nine-banded aramdillos. J. Mammal. 78: 932-941. 
McDonough, C. M. \& W. J. Loughry. 1997b. Patterns of mortality in a population of nine-banded armadillos, Dasypus novemcinctus. Amer. Midl. Nat. 138: 299-305.

Montgomery, G. G. (ed.) 1985. The evolution and ecology of armadillos, sloths, and vermilinguas. Smithsonian Instit., Washington, D.C. 451 p.

Newman, H. H. 1913. The natural history of the ninebanded armadillo of Texas. Amer. Nat. 47: 513-539.

Newman, H. H. \& J. T. Patterson. 1910. The development of the nine-banded armadillo from primitive streak to birth, with special reference to the question of polyembryony. J. Morph. 21: 359-423.

Patterson, J. T. 1913. Polyembryonic development in Tatusia novemcinctus. J. Morph. 24: 559-684.

Prodöhl, P. A., W. J. Loughry, C. M. McDonough, W. S. Nelson. \& J. C. Avise. 1996. Molecular documentation of polyembryony and the microspatial dispersion of clonal sibships in the ninebanded armadillo, Dasypus novemcinctus. Proc. R. Soc. Lond. Ser. B 263: 1643-1649.

Redford, K.H. 1985. Food habits of armadillos (Xenarthra: Dasypodidae), p. 429-437. In G. G. Montgomery (ed.). The evolution and ecology of armadillos, sloths, and vermilinguas. Smithsonian Instit., Washington, D.C. 451 p.

Redford, K.H. 1994. The edentates of the cerrado. Edentata 1: 4-10.

Redford, K.H. \& J. F. Eisenberg. 1992. Mammals of the neotropics. Vol. 2. The southern cone. Univ. Chicago, Chicago. 430 p.

Schaller, G. B. 1983. Mammals and their biomass on a Brazilian ranch. Arq. Zool. (Univ. São Paulo) 31: 1-36.

Sikes, R. S., G. A. Heidt. \& D. A. Elrod. 1990. Seasonal diets of the nine-banded armadillo (Dasypus novemcinctus) in a northern part of its range. Amer. Midl. Nat. 123: 383-389.

Storrs, E.E., \& R. J. Williams. 1968. A study of monozygotic quadruplet arrnadillos in relation to mammalian inheritance. Proc. Nat. Acad. Sci. (USA) 60: 910-914.

Taber, F. W. 1945. Contribution on the life history and ecology of the nine-banded arrnadillo. J. Mammal. 26: $211-226$

Talmage, R. V. \& G. D. Buchanan. 1954. The armadillo (Dasypus novemcinctus). A review of its natural history, ecology, anatomy and reproductive physiology. Rice Inst. Pamph. Mono. Biol. 4: 1135.

Taulman, J. F. \& L. W. Robbins. 1996. Recent range expansion and distributional limits of the ninebanded armadillo (Dasypus novemcinctus) in the United States. J. Biogeog. 23: 635-648.

U.S. Naval Observatory. 1995. The astronomical almanac. U. S. Government Printing Office, Washington, D.C. $548 \mathrm{p}$.

Wetzel, R. M. 1982. Systematics, distribution, ecology, and conservation of South American edentates, p. 345-375. In M. A. Mares \& H. H. Genoways (eds.). Mammalian biology in South America. Spec. Publ. Ser., Pymatuning Lab. Ecol., Pittsburgh. 539 p.

Wetzel, R. M. 1985. Taxonomy and distribution of armadillos, Dasypodidae, p. 23-46. In G. G. Montgomery (ed.). The evolution and ecology of armadillos, sloths, and vermilinguas. Smithsonian Instit., Washington, D.C. $451 \mathrm{p}$.

Wetzel, R. M. \& E. Mondolfi. 1979. The subgenera and species of long-nosed armadillos, genus Dasypus L., p. 43-63. In J.F. Eisenberg (ed.). Vertebrate ecology in the northern neotropics. Smithsonian Instit., Washington, D.C. $271 \mathrm{p}$. 